Vol. 2, No. 2, pp. 91-114, (June 2021)

DOI: $10.21608 / A U J E S .2021 .65951 .1013$

Aswan University Journal of Environmental Studies (AUJES)

Online ISSN: 2735-4237, Print ISSN: 2735-4229

Journal homepage: https://aujes.journals.ekb.eg/

Original research

\title{
Linking Territorial and Coastal Planning: Conservation Status and Management of Mangrove Ecosystem at the Egyptian - African Red Sea Coast
}

\author{
Abdelwahab A. Afefe \\ Nature Conservation Sector, Egyptian Environmental Affairs Agency (EEAA)
}

Received: $2 / 3 / 2021$

Accepted: 29/4/2021

(C) Unit of Environmental Studies and Development, Aswan University

\begin{abstract}
:
The present study was conducted to get the knowledge regarding the mangroves boundaries, geomorphologic forms, threats in Egypt and design a management plan to conservation of mangrove ecosystem along the Egyptian Red Sea coast, and to give the opportunity to transfer this knowledge to other neighbors countries in the Middle East and Africa. Despite the fact that the legal requirements for the protection of the mangroves stands at the Egyptian Red Sea coast are present, the lack of the demarcation and the boundary identification of these stands make mangrove a target for misuse. Even some of the stands suffered partial or complete removal. The mangroves in Egypt are growing in three main geomorphological forms: on an extensive inter-tidal flat; in an enclosed bay, protected by a coralline ridge; and mangroves growing in a sea channel. In addition, the environmental aspects of mangrove growth in Egypt can be divided into four groups: climatic conditions; geomorphological aspects of Red Sea lagoons, bays and islands; water characteristics and man-made modifications. The major threats facing the mangroves of Egypt included the exploitation of it for coastal development (urbanization); firewood, camel feed and timber by human beings; pollution, this leads to a great loss of mangrove biodiversity. It is difficult to generalize planting sites for successful mangrove restoration, as this will depend on understanding of the ecological interactions and processes (ecosystem approach) and local environmental conditions along the costal and the species to be planted. In addition, the Knowledge of mangroves species zonation is essential in determining suitable areas of different species. Therefore, urgently need to evaluate the success of rehabilitation trials of mangroves that implemented before along the Red Sea coast to contribute in success of current and future conservation activities for mangroves. Thus, our focus should be extended to improving management and policy in mangrove restoration as forest carbon stock enhancement. This holistic effort would increase the benefit of mangrove ecosystem services for communities and human beings.
\end{abstract}

Keywords: Protected Areas; Mangrove, Biodiversity Conservation; Ecosystem; Red Sea

Corresponding author*: E-mail address: abdoafefe@hotmail.com 


\section{1- INTRODUCTION}

Mangrove forests located at the interface between terrestrial, near-shore marine ecosystems, and estuarine in tropical and subtropical regions (Dodd and Ong, 2008). globally mangroves are cover about $0.7 \%$ of total area the world's tropical forests (Giri et al., 2011), and $0.12 \%$ of the total land area (Dodd and Ong, 2008). Mangroves are an important bulkhead against global warming: they afford protection for coastal areas from tidal waves and cyclones and are among the most carbon-rich forests in the tropics (Cornforth et al., 2013), almost $80 \%$ of global fish catches are directly or indirectly dependent on mangroves services (Ellison, 2008). Thus, the food security and livelihood for many coastal people communities is closely linked to the health of mangrove ecosystem (Horwitz et al., 2012). Seventy-five percent of the world mangroves are in 15 countries where only $6.9 \%$ of the mangrove areas are protected under the existing protected areas network (IUCN I-IV) (Giri et al., 2011). Less than $40 \%$ of the evaluated mangroveendemic vertebrates are in danger of extinction (Luther and Greenberg, 2009). The reduction of these communities is mainly due to local human impacts (Macintosh and Ashton, 2002; PERSGA, 2004). The mangroves in Egypt occupy about 525 hectares distributed in 28 different locations along Egyptian Red Sea coasts. One large discontinuous stand along the Gulf of Aqaba in Nabq Protected Area and one small stand at the most southern part of Gulf of Suez at Ras Mohammed National Park (Zahran and Willis, 2009). Mangroves of Egypt are consisting of Avicennia marina, except for a few stands located southern Red Sea of Egypt, near the EgyptianSudanese borders, where Rhizophora mucronata coexists along with A. marina (PERSGA, 2004). Many studies were examined to understand the adaptations, ecophysiological processes and morphological characteristics of mangrove trees growing in a per-arid area at the Red Sea coast of Egypt (e.g.Teraminami et al., 2013; Matsuo et al., 2016; Afefe et al., 2019; Afefe et al., 2020). The present study was conducted to get the knowledge regarding the mangroves boundaries, geomorphologic forms, threats in Egypt and design a management plan to conservation of mangroves and their ecosystem along the Egyptian Red Sea Coast. Also, to give the opportunity to transfer this knowledge to other neighbors countries in the Middle East and Africa.

\section{1- The Study Area}

\section{2- MATERIALS AND METHODS}

The mangroves in Egypt occupy about 525 hectares (ha) distributed in 28 different locations along Egyptian Red Sea coast, including one large discontinuous stand along the Gulf of Aqaba in Nabq Protected Area and one small stand at the most southern part of Gulf of Suez at Ras Mohammed National Park (Zahran and Willis 2009). Mangroves in Egypt are predominantly mono-specific, consisting only of Avicennia marina (grey mangroves; Avicenniaceae); except for a few locations near the Egyptian-Sudanese border area, where Rhizophora mucronata (loop-root mangrove; Rhizophoraceae) coexists along with A. marina (PERSGA 2004). (Figure 1).

\section{2- Data Inventory and Collection}

The primary qualitative data underpinning this paper was collected by the authors from June 2018 to June 2019 through the field visits to the mangroves stands at the Red Sea coast of Egypt [from $40 \mathrm{~km}$ north of Hurghada (El Gouna) to Shalateen and Halaib in the south]. The research information resources were based on primary and secondary source, where the primary sources of information depending on field visits and semi-structured interviews; and the secondary sources of information depending on articles, reports, books, etc. 


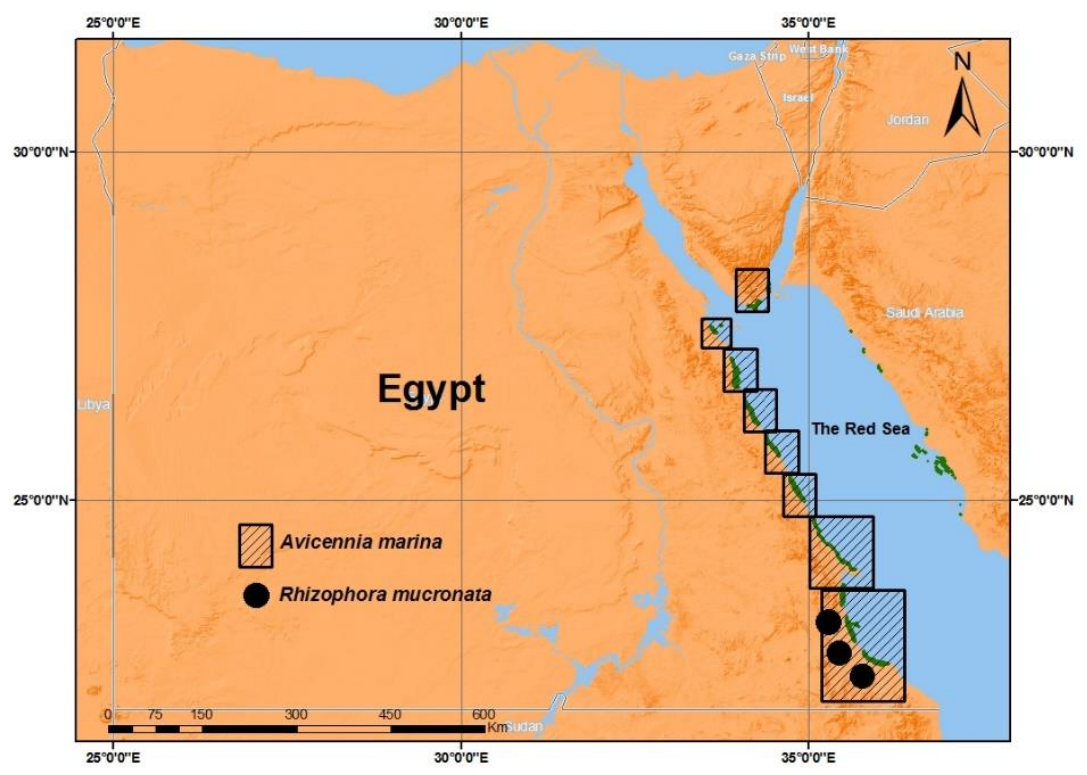

Figure 1. Map locations of the two mangrove species stands along the Red Sea and Gulf of Aqaba in Egypt

\section{3- GIS Mapping Software, Spatial Data Analytics, and Locations}

Esri Arc GIS 9.2 was used to plot the study sites to prepare the Initiate mangrove maps to show the locations of the study sites and to prepare the mangrove management plan. In addition, the altitude was recorded for each site to use as an ecological gradient (Meaden and AguilarManjarrez, 2013).

\section{4- Data Analysis and Reporting}

Their many methods used included: SWOT analysis tries to establish a strategic fit between an organization's internal strengths and weaknesses and opportunities and threats posed by its external environment. In the SWOT analysis, strategies an organization adopts should match the environmental challenges and opportunities and the organization's weaknesses and especially its strengths. (Beer et al., 2005). Venn diagram of stakeholders: a tool that helps to understand who will be affected by proposed development activities, and this tool used in this study to analyze links between the most important stakeholders in the study area (FAO, 2001). The mangroves management plan in the present study were designed according to the global conservation guidelines for marine protected areas that need to preserve mangroves and enhance it ecosystem with analysis of threats and pressure that facing of mangroves protection (Nellemann et al., 2009; Tundi et al., 2011; Flint et al., 2018; Slobodian et al., 2018).

\section{3- RESULTS AND DISCUSSION}

\section{1- Climate Conditions and Topography of Mangroves Areas in Egypt}

From a geographical point of view, the Egyptian mangroves can be divided into the Sinai mangroves, and mangroves growing on the Egyptian-African Red Sea coast (PERSGA, 2004). The mangroves in Egypt are predominantly mono-specific, consisting only of $A$. marina (Avicenniaceae), and R. mucronata is only limited to a few localities (Figure 2) around the Egyptian-Sudanese border area (Zahran and Willis 2009). The current findings agree with Afefe 
et al. (2019) they suggested that the environmental aspects of mangrove growth in Egypt can be divided into four groups: climatic conditions; geomorphological aspects (Red Sea lagoons, bays and islands); water characteristics and man-made modifications. The present findings agree with Fouda and Gerges (1994), who reported that, the mangroves of Egypt are growing in three main geomorphological forms along the Red Sea and South Sinai coastline in Egypt: a mangrove community growing on an extensive inter-tidal flat; in an enclosed bay, protected by a coralline ridge; and in a channel (Figure 3).

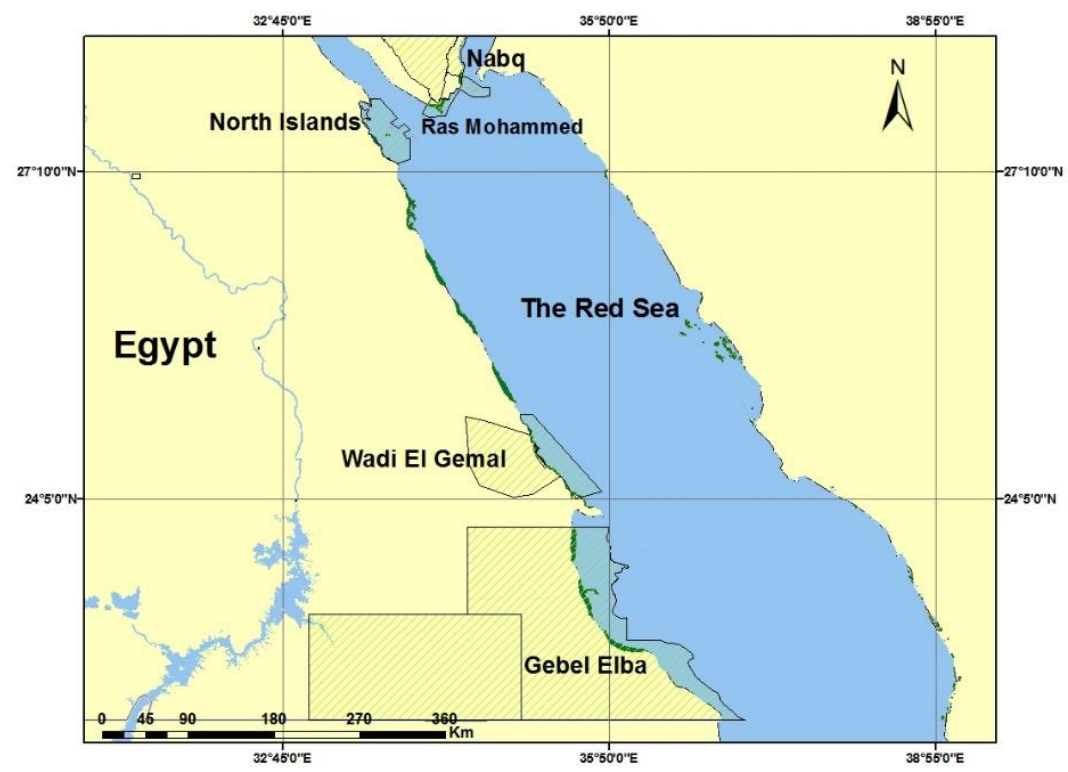

Figure 2. Map of mangroves stands in Egypt (green plots) and borders of Protected Areas network (redlines) using Arc GIS

In addition, EEAA (1998) reported on the description and definition of the Red Sea geomorphological aspects, an extensive reef flat is found along most of the shore, but in wadis areas (the mangroves locations) other features are noted as following: A 'sharm' which is an area where freshwater runoff from the wadi creates a ' $\mathrm{V}$ ' shaped channel; A 'marsa', which is usually a natural harbour in the form of a semi-enclosed inlet through the reef flat (scattered in several places along the Egypt's Red Sea shores); 'bays' (e.g. Abu Soma) which are larger sandy inlets where there is no reef flat. Other areas have a dominant - 'Ras' which is a coralline headland extending outward toward the sea, for example Ras Banas. Moreover, the present findings agrees with Zahran and Willis (2009) that the usual habitat of the mangroves along the Egyptian Red Sea coastline is the shallow water along the shore, especially in: lagoons, bays, coral or sand bars parallel to the shore, where in a few localities, A. marina grows on the terrestrial side of the shoreline, and in one locality (delta of Wadi Gemal, south of Marsa Alam) the bushes are partly covered by sand hillocks, and this situation is apparently due to the silting of the shoreline zone originally occupied by the mangrove.

However, through the field observation with a literature review (e.g. EEAA, 1998; Zahran and Willis, 2009), in the present study we designed a diagram of coastal morphological features: sharms, marsas, bays, islands, submerged reefs and the mangroves position (Figure 4; 5). 


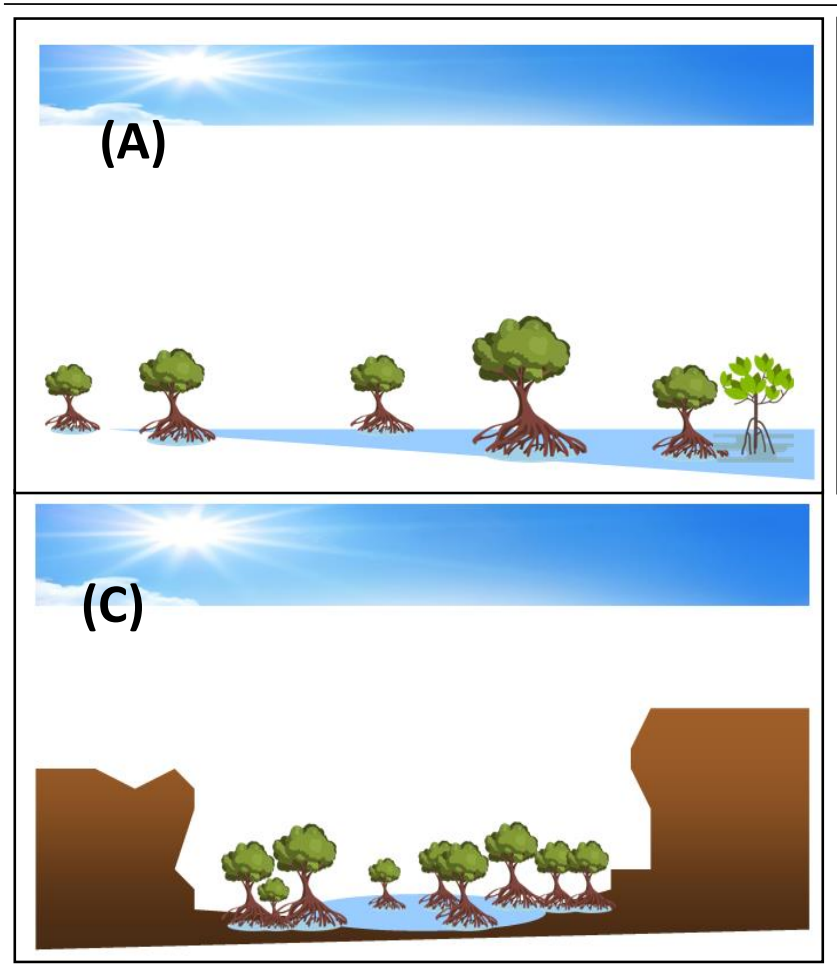

(B)

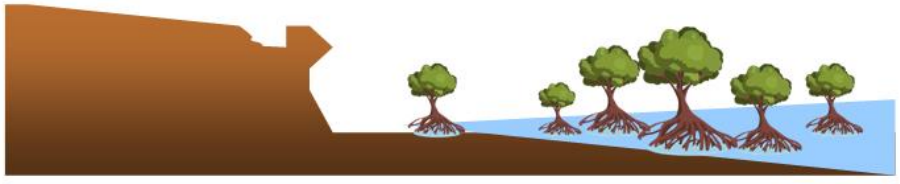

Legend:

(A): A mangrove community growing on an extensive intertidal flat (Marsa Shaab, South Shalatine - Gebel Elba);

(B): An example of a mangrove community growing in an enclosed bay, protected by a coralline ridge $(23 \mathrm{~km}$ South of Safaga);

(C): A mangrove community growing in a channel (Ras Mohammed, South Sinai)

Figure 3. The three main geomorphological forms of mangroves in Egypt

However, the mangroves in the southern Red Sea of Egypt are more continuous than in the northern Red Sea, where mangroves are only restricted to a narrow favorable habitats (Zahran and Willis 2009). On the other hand, the freshwater seems to be a controlling factor in mangrove growth, since a previous study in Qatar (Batanouny, 1986) concluded that mangrove growth sites must receive freshwater from inland, either as overland flow or as underground seepage and the rainwater plays another role in mangrove growth: it washes salts secreted on the leaves. Moreover, the source of surface water all over the Eastern Desert in Egypt and north of Sudan is the rainfall on the chains of the Red Sea mountains (Hassib, 1951). In the present study, the land areas of Egypt's Red Sea coast are dominated by a backdrop of rugged mountains running parallel to the shore (Figure 6), and these mountains (up to 2000 meters high) create a series of coastal seaward draining watersheds and "wadis", resulting in extensive alluvial plains or deltas as they reach the sea (EEAA, 1998). However, Zahran and Willis (2009) reported, the structure of the mangrove vegetation on the Red Sea coast of Egypt is simple - usually a single layer of $A$. marina. In localities where $R$. mucronata is included, this forms a stratum towering over that of A. marina.

\section{2- Threats Analysis}

The present study results have shown that a considerable area of the mangroves is exposed to destruction and the major threats to the mangrove forests in the Egyptian Red Sea coast due to the following impacts:

1) Coastal development (urbanization) as removal for constructing roads, houses, hotels, and other infrastructure (El Gouna and El Qusier)

2) Destructive unregulated fishing practices along the coast (overfishing)

3) Pollution "e.g., oil spills, tar balls phosphates" (north islands) 
4) Accumulation of solid waste along the coast.

5) Woodcutting for wood and charcoal (Wadi El Gemal to Gebel Elba)

6) Camel Grazing (Wadi El Gemal and Gebel Elba)

7) Plant Diseases (Abu- Monkar island)

8) Irresponsible tourism such as Human trampling, disturbance, and souvenir collection (El Gouna, Safaga, El Qusier and Wadi El Gemal)

9) Habitats Change / Destruction (Hydrological changes through coastal roads and jetties) along the coast.

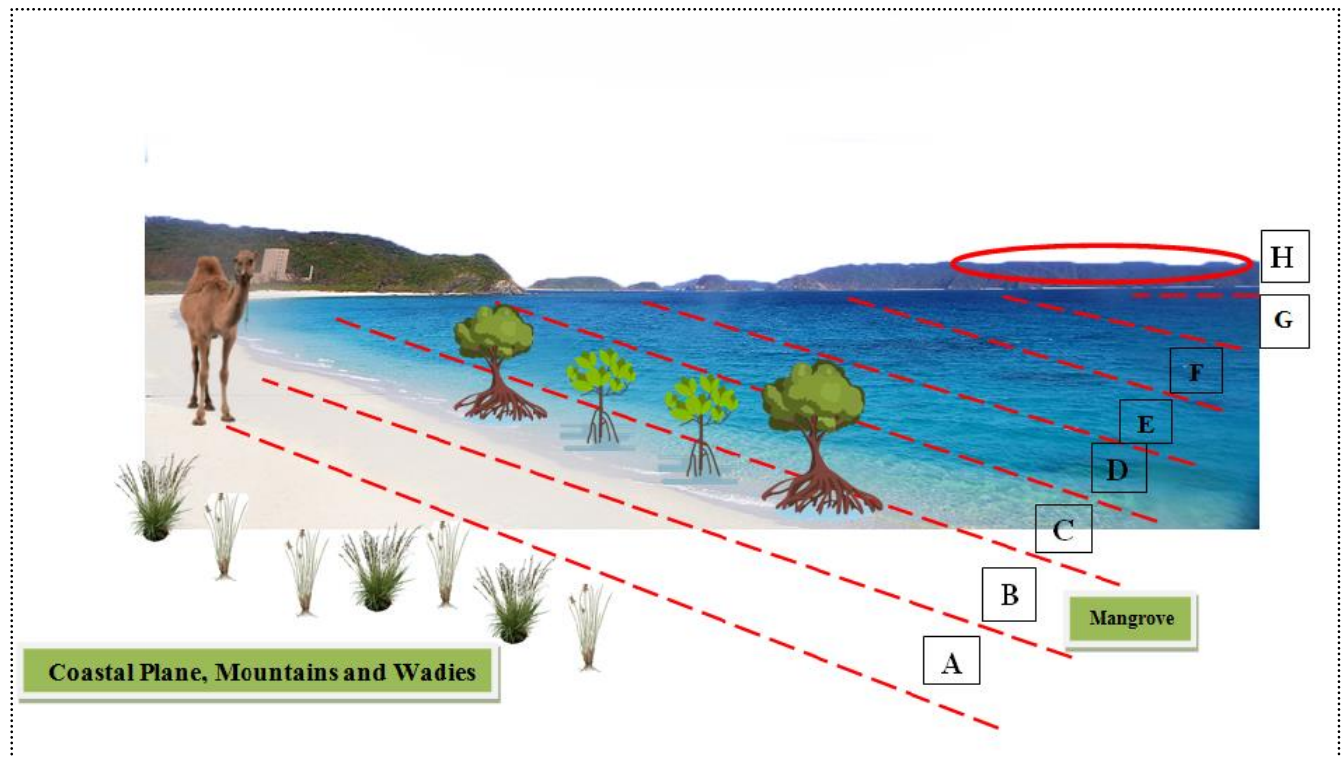

Legend: $\mathbf{A}=$ supra tidal zone; $\mathbf{B}=$ intertidal zone; $\mathbf{C}=$ reef flat; $\mathbf{D}=$ reef edge;

$\mathbf{E}=$ reef wall $; \mathbf{F}=$ coral patches $; \mathbf{G}=$ submerged reefs and $\mathbf{H}=$ islands

Figure 4. Cross-sectional diagram of marine and terrestrial zones in Red Sea

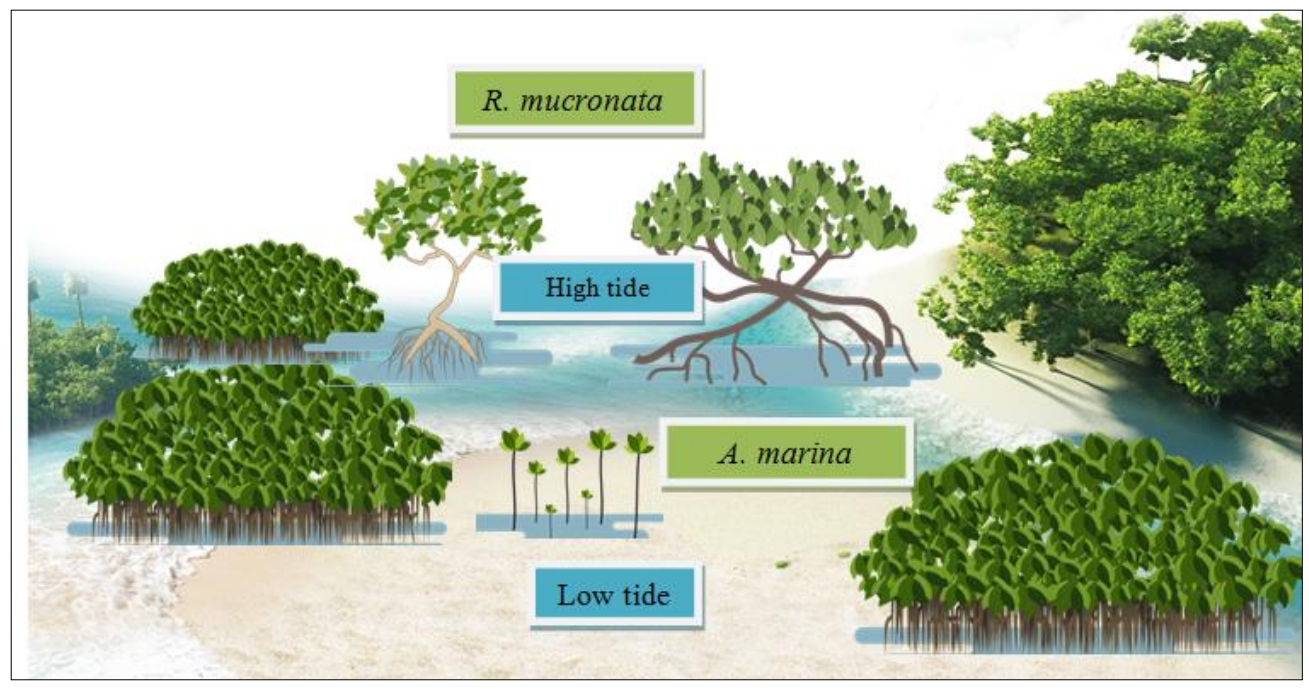

Figure 5. Diagram showing the common distribution of Mangrove in mixed communities. 


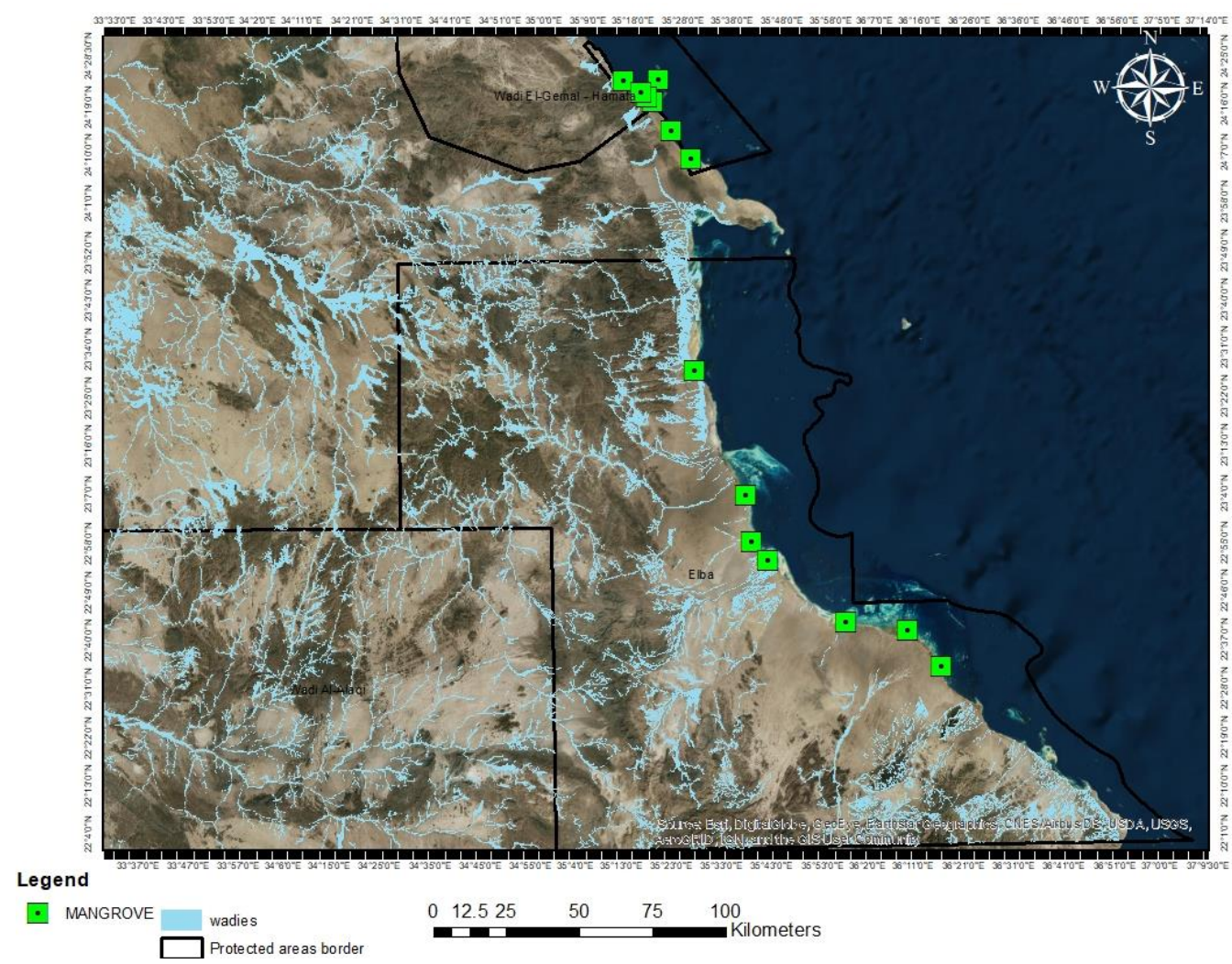

Figure 6. Map of water streams and flows wadies at south of Egyptian Red Sea Coast, with focusing on mangrove main stands in Gebel Elba Protected Area

Mangroves are often perceived as muddy, mosquito infested wastelands or useless trees growing on the shore. Yet, they are actually valuable reservoirs of coastal-marine biodiversity. Due to lack of awareness, the Red Sea mangroves have been continually cut down for land access, wood or grazing area over time. This situation is somewhat better since Prime Ministerial decree No. 642/1995 has declared all the mangroves on the Red Sea coast as protected areas. Until now there were no mapping or boundary demarcations with the decree showing the location of the mangrove stands on the coast (EEAA, 1998).

The present study found that: the studies assessing the impacts of mangrove degradation on the ecosystem and associated communities in the Red Sea are generally scarce. The camel grazing was reported in most mangroves in the region as a major problem causing mangrove degradation (Wadi El Gemal and Elba Protected Areas), excluding only a few stands growing in protected islets along the Red Sea coast. The intensity of camel browsing varied from low at some areas to moderate at most of the mangrove stands and severe at some others. This depends on the size of the camel herds present in the area, accessibility of the site, and the availability and condition of another pastoral resource in the coastal area.

In addition, cutting provided passages to the inner dense parts of the stands for camels, making these parts more accessible for grazing. Thus, the combined effects of grazing and cutting have accelerated degradation of several mangrove areas near major population settlements in the region (PERSGA, 2004). However, the majority of Bedouins along Red Sea coastline (87\%) are aware of the importance of mangroves and the need for conservation; the main traditional activities undertaken by Bedouins are livestock raising, minor seasonal agriculture, horticulture and fishing. However, Bedouins are increasingly getting involved in tourism (EEAA, 2009). 
On the other hand, Pollution by domestic solid wastes (e.g., polyethylene sacs and bottles, plastic, and metal cans) was also reported as a problem in many mangrove areas of the Red Sea as recorded in (Abo Monkar Island in Hurghada, Safaga and El Qusier areas). It is particularly encountered where disposal in large quantities occurs near population centers of the major coastal towns and villages, solid wastes may have physical impacts by enfolding the young seedlings and pneumatophores, blocking tidal channels, and causing disturbance to the mangrove associated fauna (Najeeb et al., 2015). Other potential pollution threat to mangroves in the Red Sea include oil spills, mangroves are particularly vulnerable to oil (Red Sea islands), both through direct toxicity from the lighter hydrocarbon fractions and by interfering with the root ventilation system, whereby oxygen is delivered to their roots. The Red Sea region forms one of the major thoroughfares for international maritime traffic in world and its largest producer and exporter of oil in world (Saenger and Khalil, 2007). These factors place the region's mangroves at high risk.

The major cause of the mass mortality and top dying of the mangrove trees appeared to be localized modifications in the topography of the coastal area, leading to diverting tidal water away from mangroves, decreasing water levels in the mangrove channels/lagoons, and reduction in the mangrove area inundated by tidal water in the upper reaches of the stands, where this can mostly be attributed to construction activities involving dredging and sediment dumping in the shore areas, This problem has been addressed from many author (e.g. PERSGA, 2004; Khalil, 2001).According to TNC (2000), the TNC's 5-S Framework describes four variables used to measure threats including low, medium, high and very high ranks (Table 1).

Table 1. Describes the four variables used to measure threats at mangroves.

\begin{tabular}{|c|c|c|c|c|c|c|c|c|}
\hline \multirow[b]{2}{*}{ Threats } & \multicolumn{8}{|c|}{ Location } \\
\hline & $\begin{array}{l}\text { North } \\
\text { Islands }\end{array}$ & $\begin{array}{c}\text { El- } \\
\text { Gouna }\end{array}$ & Safaga & Qusier & $\begin{array}{l}\text { Marsa } \\
\text { Alam }\end{array}$ & $\begin{array}{c}\text { Wadi El } \\
\text { Gemal }\end{array}$ & $\begin{array}{c}\text { Marsa } \\
\text { Hemara }\end{array}$ & $\begin{array}{c}\text { Gebel } \\
\text { Elba }\end{array}$ \\
\hline $\begin{array}{c}\text { Coastal } \\
\text { development } \\
\text { (urbanization) }\end{array}$ & Low & $\begin{array}{l}\text { Very } \\
\text { high }\end{array}$ & Medium & $\begin{array}{l}\text { Very } \\
\text { high }\end{array}$ & $\begin{array}{l}\text { Very } \\
\text { high }\end{array}$ & Low & high & Low \\
\hline $\begin{array}{c}\text { Destructive } \\
\text { unregulated } \\
\text { fishing } \\
\text { practices }\end{array}$ & $\begin{array}{l}\text { Very } \\
\text { high }\end{array}$ & Medium & high & Medium & Medium & Low & Medium & Low \\
\hline Pollution & $\begin{array}{l}\text { Very } \\
\text { high } \\
\end{array}$ & Medium & high & Medium & Medium & Low & Medium & Medium \\
\hline $\begin{array}{l}\text { Wood } \\
\text { cutting }\end{array}$ & Low & Medium & Medium & high & high & Medium & Medium & Medium \\
\hline $\begin{array}{l}\text { Animal } \\
\text { Grazing }\end{array}$ & Low & Low & Low & Low & Low & $\begin{array}{l}\text { Very } \\
\text { high } \\
\end{array}$ & $\begin{array}{l}\text { Very } \\
\text { high } \\
\end{array}$ & $\begin{array}{l}\text { Very } \\
\text { high }\end{array}$ \\
\hline $\begin{array}{c}\text { Plant } \\
\text { Diseases }\end{array}$ & $\begin{array}{l}\text { Very } \\
\text { high } \\
\end{array}$ & Medium & Medium & Medium & Medium & Medium & Medium & Medium \\
\hline $\begin{array}{c}\text { irresponsible } \\
\text { tourism }\end{array}$ & $\begin{array}{l}\text { Very } \\
\text { high }\end{array}$ & $\begin{array}{l}\text { Very } \\
\text { high }\end{array}$ & Medium & $\begin{array}{l}\text { Very } \\
\text { high }\end{array}$ & $\begin{array}{l}\text { Very } \\
\text { high }\end{array}$ & high & high & Low \\
\hline $\begin{array}{c}\text { Habitats } \\
\text { Change / } \\
\text { Destruction }\end{array}$ & high & $\begin{array}{l}\text { Very } \\
\text { high }\end{array}$ & Low & $\begin{array}{l}\text { Very } \\
\text { high }\end{array}$ & $\begin{array}{l}\text { Very } \\
\text { high }\end{array}$ & Medium & high & Low \\
\hline
\end{tabular}


One of the key activities by the the Egyptian Environmental Affairs Agency (EEAA) are the detailed surveys of the 28 different mangrove stands in Sinai and Red sea governorates. The plant life in the Red Sea coastal shoreline and the Eastern Desert in Egypt is rather rich and interesting, where considerations of the exploitation and conservation of natural vegetation must take ecological principles into account (Afefe 2021). The sustainable management of natural vegetation in Egypt requires stopping the severe human impacts that lead to eliminating certain plant populations and modifying the complex plant communities into simple fragile onces (Afefe 2020; Abbas et al. 2016; Afefe et al. 2016). Moreover, despite the fact that the legal requirements for the protection of the mangrove forests in Egyptian Red Sea coast are present, the lack of the demarcation and the boundary identification of these stands make mangrove a target for misuse. Even some of the stands suffered partial or complete removal.

\section{3- The Conservation Action}

The management Plan for Conservation and Sustainable Use of Mangroves along the Egyptian Red Sea Coast.

\subsection{1- Overall and Specific Objectives}

The overall objective of this action plan is to promote the protection, rehabilitation and wise use of Egypt's mangrove ecosystem towards sustainable development so that the protection function, values and its biodiversity could meet the need of socio-economic development and environmental protection along the Red Sea coastline.

The specific Objectives included: (1) Establish a guidelines for mangrove ecosystem management; (2) Develop the administrative capacity for the management of mangroves in Egypt; (3) Promote sustainable management of mangrove forest responding to climate change and to mitigate its effects; (4) Reinforce the effectiveness of mangrove ecosystem protection, rehabilitation and development; (5) Contribute to livelihood improvement for the local communities who live vicinity of mangrove area; (6) Support research and development of Egypt's mangrove forest; (7) Increase public awareness and education on the benefits of the mangrove forests, responses to global climate change, and conservation values of rare and precious gene sources.

\subsection{2- The Action Plan}

\subsubsection{1- Management Framework}

The wise management needs to be rooted in a thorough understanding of the mangrove ecosystem approach. The management cycle illustrated (Hockings, 2006), identifies six important elements (Figure 7) in this process that should, ideally, all be assessed if effectiveness of management is to be fully understood.

Management of mangroves begins with understanding the context of the mangrove ecosystem in the study locations, including its values, the threats that it faces and opportunities available for conservation actions, its stakeholders, the management procedures, law and political environment in Egypt.

The mangroves management for sustainability requires managing to provide for ecological, economic and social benefits over time. This entails implementing strategies that meet the needs of the present and the future. It means practicing a land stewardship ethic, which integrates and 
continuous update the mangrove management plan with conservation plans of flora, wildlife, soil, and water quality.

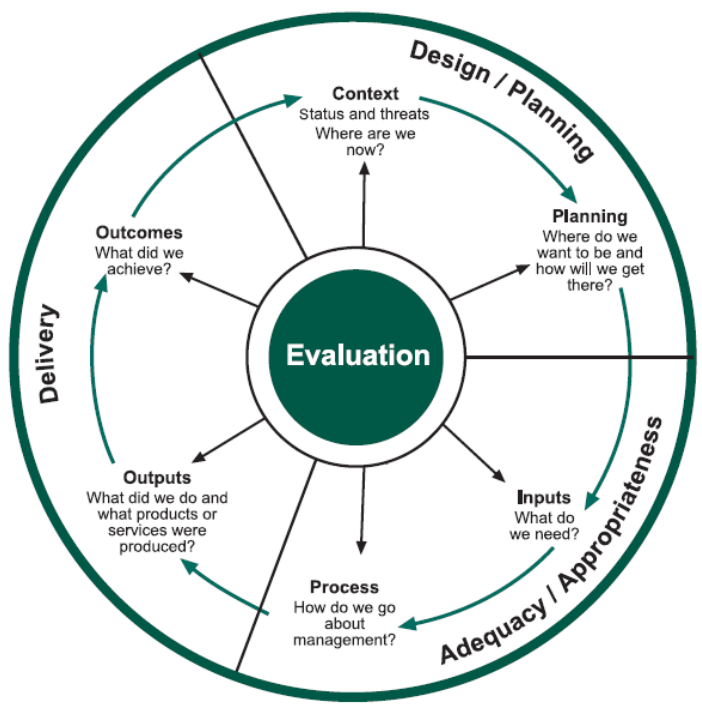

Figure 7. The Framework for assessing management effectiveness of protected areas (Hockings, 2006).

\subsubsection{2- Venn Diagram Stakeholder's Analysis}

In order to safeguard sites and their features includes of the vegetation cover, the management of mangrove area must adopt a flexible approach that will allow responding to the legitimate interests of stakeholder, accommodating uncertain and variable resources, and surviving the vagaries of the natural (Ramsar, 2010). Venn diagram is tool to learn more about the importance of local groups and institutions in the present study locations to management and conservation of mangrove (FAO, 2001). However, Venn diagram of stakeholders in Red Sea governorate is important to analysis of links between the most important stakeholders in Red Sea governorate that related and impacts on natural vegetation cover and mangrove areas is important for performance management processes. Venn diagram tool from stakeholder's priorities for development toolkit important to learn more about Red Sea Protected Areas (Red Sea coastal line) and it is linkages with other local institutions, organizations and agencies in area. The degree of linkages and importance of contacts are shown in Figure (8).

Ownership of Mangroves Areas: In past the mangroves were tended to marginally defined and placed under many institutions with conflicting roles such as Ministry of Environment, Ministry of Agriculture, defense and local authorities (governorates), but now the responsibility mainly placed under EEAA as coordinator with other stakeholders. EEAA is responsible for conservation of biodiversity and management of natural resources in whole country. Most of stakeholders in Red Sea governorate have a direct or indirect role and affect or be affected by the conservation actions of natural vegetation included mangrove forests. The EEAA, Red Sea governorate, Ministry of Defense (Borders guards), General Authority for Development of Fish Resources, Tourism Ministry and Petroleum Ministry are considered as most important actors that have effects on protection of mangrove forests along the Egyptian Red Sea Coast. However, 
the role of EEAA is important in achieving good relation with the governmental authorities, local community and economic activities owners.

\section{Legend}

\begin{tabular}{|l|l|}
\hline EEAA & Egyptian Environmental Affairs Agency \\
\hline LCO & Local Communities \\
\hline FMN & Fishermen \\
\hline MDS & Ministry of Defense (Borders guards) \\
\hline GDF & $\begin{array}{l}\text { General Authority for Development of } \\
\text { Fish Resources }\end{array}$ \\
\hline LTO & Local Tourism Owners \\
\hline VTS & Visitors and tourists \\
\hline MT & Ministry of Tourism \\
\hline MPC & Mining and Petroleum Companies \\
\hline MPT & Ministry of Petroleum \\
\hline MWR & $\begin{array}{l}\text { Ministry of Water Resources \& } \\
\text { Irrigation }\end{array}$ \\
\hline URI & Universities and Research Institutions \\
\hline RSG & Red Sea governorate \\
\hline
\end{tabular}

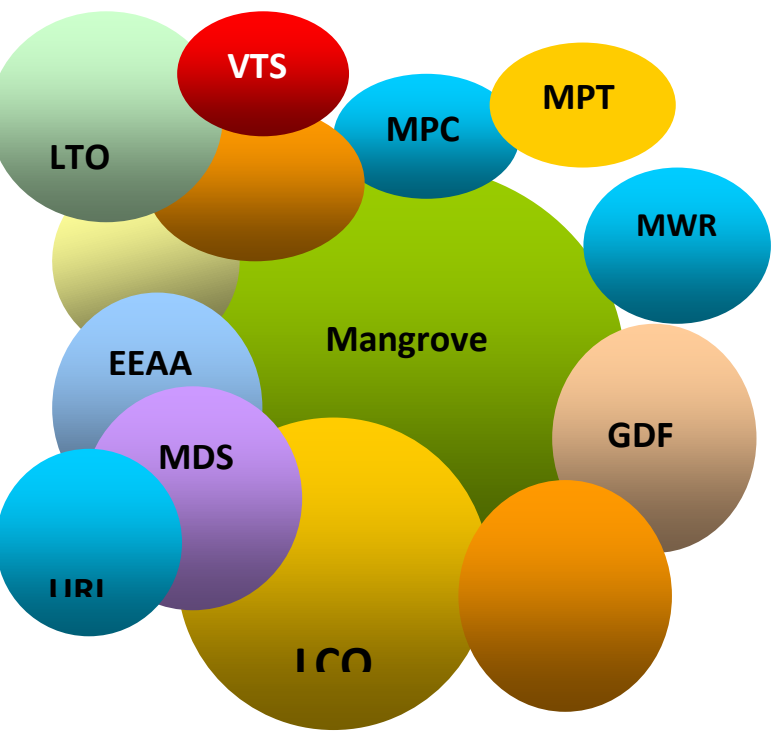

Figure 8. Venn diagram of stakeholders in Red Sea governorate that impact on mangroves.

The importance of incorporating a more participatory approach into protected area decision-making processes in order to foster the implementation of biodiversity conservation strategies has been widely recognized in the literature (Anthony, 2007; Reed, 2008). However, when local communities and their needs and aspirations are ignored are excluded from protected areas management, it becomes extremely difficult to enforce conservation policies (Aswani and Weiant, 2004). The Logical Framework Approach is an analytical process and set of tools used to support objectives-oriented project planning and management (Milica, 2011).

Another essential factor in determining the success of a restoration activity for the mangrove is the level of co-operation of the local community and their leaders. The pressure of the local population will influence the structure and functions of mangrove systems that surrounds them (Kairo, 1995b; Dahdouh-Guebas et al., 2000). At the regional level, a regional convention (Jeddah Convention) was adopted in 1982, which has led to the establishment of the regional Organization for the conservation of the environment of the Red Sea and Gulf of Aden (PERSGA) in 1996, that has seven member countries (Egypt, Sudan, Djibouti, Yemen, Somalia, Saudi Arabia, and Jordan) and it executes multi-linked programme activities addressing management and conservation of marine resources in the Red Sea region, of which mangroves is one of the key components (PERSGA, 2011). In addition, the environmental education and public awareness can contribute to active involvement and greater public participation includes local communities in issues related to mangrove conservation, sustainable use and management. When management decisions incorporate local inputs they will succeed, and political support will be greater when the public is satisfied that it has been heard and had an opportunity to become involved. 


\subsubsection{3- SWOT Analysis}

A SWOT analysis as following will give more information to identify the key internal and external factors that are important to conservation of mangrove in Egypt.

a) Strengths: (1) Possibility of enforce the rules of the EEAA for EIA and protected areas; (2) The relations with main stakeholders; (3) Availability of a preliminary "management plan" in order to conservation of mangrove.

b) Opportunities: (1) Law $102 / 1983$ for protected areas and 9/2009 for Environment; (2) Designated selected areas by Ramsar as Wetland of International Importance; (3) Identified the Gebel Elba area as one of twenty important plant areas (IPAs) in Egypt; (4) Implement community awareness/ education programs to promote the unique environmental qualities and characteristics of the area.

c) Weaknesses: (1) A lack of EEAA funding for the upkeep and maintenance of vehicles and equipment and conservation of mangrove need funding to maintain an appropriate amount of staff within the protected areas; (2) Shortage of botanist researchers in EEAA; (3) Shortage of awareness \& education programs to local community and economic activities owners.

d) Threats: (1) Infringements at natural areas and habitat destruction; (2) The negative human impacts (overgrazing, pollution, ..etc.)

\subsubsection{4- The Management plan activities}

The Management plan is contains a five major activities and programmes that may respond to the objectives to management and conservation of mangrove in Egypt. The plan including five suggested activities to help in conservation of mangrove forests in Egypt as following:

\section{Activity 1: Establish Reference Collections and Data Bank:}

The data bank will provide the Red Sea Protected Areas with information necessary for assessing the operation of the management plan and means of its development. A data bank is a computerized depot for data on biodiversity (with its various elements), ecological monitoring and research results. It will contain a geographical information system (GIS) for Red Sea coast. This will eventually be a part of the national network of data-bases of protected areas and biodiversity in Nature Conservation Sector inside Egyptian Environmental Affairs Agency. Also the data bank will issue periodical reports on the status of conservation and sustainable use of natural resources.

\section{Activity 2: Programme of Research and Studies}

There will be need of research work on population and ecosystem dynamics, assessment of ecological changes, ecological responses of the species, etc. Environmental impact studies related to new development schemes (the new projects, tourism activities, etc.) need to be carried out and submitted to EEAA. There many of intensive economic activities needs to effective management measures.

\section{Activity 3: Mangroves Rehabilitation and Restoration programmes}

In response to the dramatic loss of plant species, the disciplines of reintroduction biology and restoration ecology have emerged during the last decades. Therefore, urgently need to 
evaluate the success of rehabilitation trials of mangroves that implemented before along Red Sea coast in Egypt and other countries to contribute in success of current and future conservation activities for mangroves.

The present study agrees with Field (1996) that it is difficult to generalize planting sites for successful mangrove restoration, as this will depend on local environmental conditions and the species to be planted. It is generally agreed that the hydrologic regime is the single most important overall site condition governing the survival and subsequent growth of the mangrove seedlings. It is important that mangrove plantings be carried out on low energy areas where coastal erosion is minimal (Kairo, 1995a). When contemplating mangrove rehabilitation, special attention must be paid to soil stability and flooding regime (Pulver, 1976), site elevation (Hoffman et al., 1985), tidal and wave energy (Field, 1996), propagule availability (Kairo, 2001), propagule predation (Dahdouh-Guebas, 2001), spacing and thinning of mangroves (FAO, 1985; Kairo, 2001), nursery techniques (Siddique et al., 1993), monitoring (Lewis, 1990), community participation (Kairo, 1995b) and total cost of restoration measures (Field, 1998).

Knowledge of mangrove species zonation is essential in determining suitable areas for different species. Where, Rabinowitz (1978), while commenting on the distribution patterns of mangroves, noted that species zonation in mangroves was as a result of environmental tolerance and physiological preferences of the individual species. Each species of mangrove has a specific range of tolerance of environmental variables (salinities, tidal flooding, shading, elevation of the land etc.) that restricts it to the zones in which it preferably resides. For example Avicennia marina can tolerate high salinity levels found on the landward side of the intertidal areas (Kairo, 2001).

In Africa, for instance, there are clear cut mangrove areas at Gazi Bay (Kenya) that will never recover naturally without human intervention. Additionally, in Tanga (Tanzania) and Ngomeni (Kenya), salt work ventures have created wastelands. In addition, urban and coastal development in the Zambezi district of Mozambique have removed large areas of mangrove forests, devastating far more land than was actually required, and therefore affecting the lives of subsistence coastal dwellers quite unnecessarily (Semesi, 1998; Dahdouh-Guebas et al., 2000).

A review of the available literature on mangrove plantation establishments shows mixed successes of restoration efforts (Ellison, 2000), even though it has been said that mangrove wetlands are easy to restore and create (FAO, 1994). Whereas the lost mangrove plant species can be returned (Kairo, 1995a), a restored forest may or may not function as the original predisturbed system (McKee and Faulkner, 2000). This is especially true where there is no natural model, simple or complex, on which to base the recreated mangrove stand (Field, 1998). In East Africa, information on earlier mangrove plantation practices is scanty. Reference is made to mangrove planting in Lamu, Kenya, after the trees were clear-felled during the First World War (1914-1918) by Smith and McKenzie Company (Roberts and Ruara, 1967). In Tanzania, attempts to replant mangroves in the abandoned saltpans of Tanga district failed probably because of environmental factors (e.g. soil salinity and acidification) as well as poor species selection (Semesi and Howell, 1992). Armstrong and Seddon (2008) reported that it is undisputed that species decline is caused by extrinsic factors such as habitat alteration due to human activities and other components of global change. 
Factors affecting restoration success: Frequently the mangrove stands are permanently destroyed, but under some conditions the forests regenerate or can be restored. In very rare cases, new areas can also be created for mangrove growth (Saenger and Siddique, 1993). However, mangrove restoration has a big potential to increase the mangrove resources, provide employment to local population, protect fragile tropical coastlines and perhaps also to enhance biodiversity and fisheries productivity. Mangrove a forestation is proceeding at a large scale in Bangladesh, India and Vietnam principally to provide protection in typhoon-prone areas as well as to generate economic benefits to the poor coastal communities (Saenger and Siddique, 1993).

Fortunately, through a cooperative project between the Ministry of Agriculture and Land Reclamation, Egyptian Environmental Affairs Agency, and the International Tropical Timber Organization (ITTO) silviculturing and rehabilitation of mangrove plants (A. marina and $R$. mucronata) in representative sites of the shoreline of the Red Sea of Egypt have been successfully conducted (Anonymous, 2006). About 50 feddans have been cultivated with these two mangrove species, and rehabilitation of about 5 feddans has been also conducted during 2003 to 2007 through the project of ITTO (EEAA, 2009).

\section{Activity 4: Monitoring Programme}

Over time, natural areas are susceptible to gradual changes that have drastic effects to their overall health. Biodiversity monitoring programme is important to assess the condition and any changes in the mangrove stands along the Red Sea coast. A function of monitoring in the context of mangrove management planning is to measure and assessment the management effectiveness. This activity will aim at establishing an operative environmental for mangrove. The function of this network is to feed the data bank with up-to-date reports on the status of the vegetation cover and other elements that effect in the mangrove and coastal natural vegetation such as over-grazing, over-cutting and other unsustainable activities. Monitoring of restored areas: Once the restoration programs have been completed, it is essential to monitor recovery processes (or lack thereof) of the plots. Moreover, in a restored mangrove forest in Kenya, significant differences in faunal composition and diversity were observed five years after planting (Bosire, 1999).

\section{Activity 5: Public Awareness}

The purpose of this activity is to raise the awareness of people of all ages to ensure their support to, and participation in, the operations of the Protected Areas and in particular conservation of mangrove, coral reef and other biodiversity aspect.

This activity is a shared priority and may include:

- Guided visits of school and university students to parts of the Red Sea Protected Areas and its Visitors' Centre, these visits will be available to all students of different governorates.

- Special workshops for the NGOs interested in fields of environment and conservation, to be informed about activities in the Egyptian Red Sea Protected Areas and to solicit their support and participation.

In Egypt, many Key livelihood values and services are offering and providing by mangrove such as: fishing, livestock raising (mainly camels and goats), tourism, use of timber (for cooking, light structure, animal feed, use of firewood for tourism), employment at the 
protected areas (as community guards), erosion and flood protection, attractive landscape, and refuge for many wildlife species (EEAA, 2009).

\subsubsection{5- Mitigating Climate Change Through Conservation of Mangrove Ecosystem in Egypt}

The importance of mangrove to global climate change is motivating mangrove conservation and restoration around the globe. As the United Nation Convention on Climate Change (UNFCCC) has provided a mechanism for financing forest restoration, conservation and management (Crooks et al., 2011). The role of mangroves in global carbon cycles has been somewhat overlooked, because of their relatively small total area and often lower physical build than many tropical forests (Spalding et al., 2010). The Greenhouse Gas Emissions (GHG) from mangroves can be estimated from carbon stock changes in carbon pools that comprise of several compartments (ie. above and below-ground biomass, and soils) (Kauffman and Donato, 2012). The removal or conversion of mangrove to other land use could have significant consequences for marine ecosystem primary production and contribute to substantial greenhouse gas (GHG), to the atmosphere (Pendleton et al., 2012).

However, the carbon stocks and emission from mangrove forests have been well studied at global and national level recently, thus, our focus should be extended to improving management and policy in mangrove restoration as forest carbon stock enhancement. For Egypt case: Afefe et al. (2020) reported that, the average biomass per hectare of the Egyptian mangroves was 74997.1 and $22536.8 \mathrm{~kg}$ for A. marina and $R$. mucronata, respectively and they estimated organic carbon content for the Egyptian mangroves (525 ha) was $17.73 \mathrm{Gg} \mathrm{C}$ for biomass and $5.97 \mathrm{Gg} \mathrm{C}$ year-1 for soil: a total of $23.7 \mathrm{Gg} \mathrm{C}$ (Figure 9).

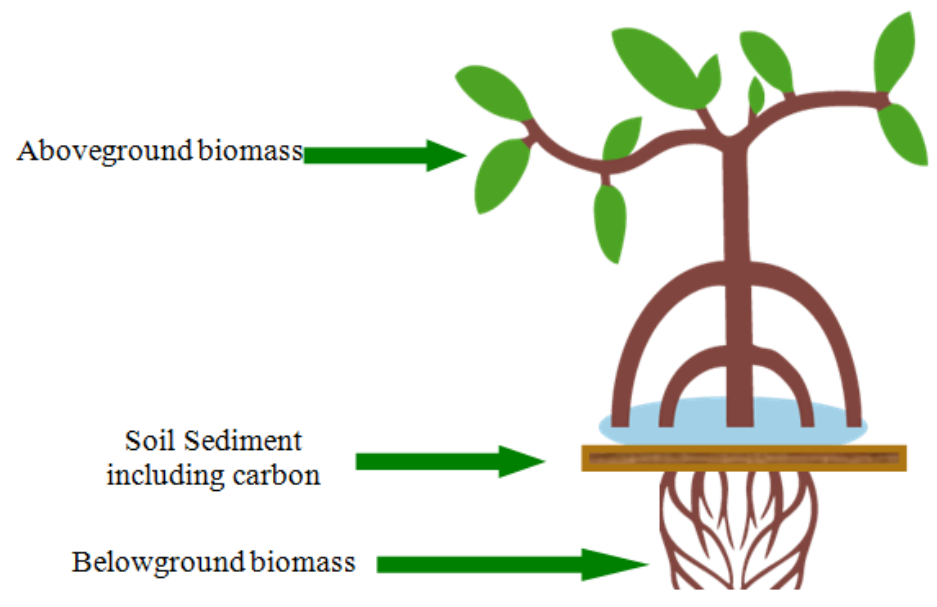

Figure 9. Carbon pools in mangrove ecosystem

The Egyptian government aims to achieve Greenhouse Gas (GHG) emission reduction targets and the information of the carbon stored by mangroves of Egypt is available currently. This information will support sound policy decision and mangroves management for climate change mitigation. However, the current study highlights the importance of strengthening GHG emission inventory by further involvement of mangroves carbon into carbon forest accounting at the Egyptian national level. The EEAA with other national institutions is continuously 
developing systems for improved estimates of annual emission; increased cooperation for monitoring, reporting and verification emission reductions is needed to bring together scientists and policy makers develop a scientific based policy of carbon accounting.

\section{Conclusion}

Despite the fact that the legal requirements for the protection of the mangroves stands at the Egyptian Red Sea coast are present, the lack of the demarcation and the boundary identification of these stands make mangrove a target for misuse. Even some of the stands suffered partial or complete removal.

The mangroves in Egypt are growing in three main geomorphological forms: on an extensive inter-tidal flat; in an enclosed bay, protected by a coralline ridge; and mangroves growing in a sea channel. In addition, the environmental aspects of mangrove growth in Egypt can be divided into four groups: climatic conditions; geomorphological aspects of Red Sea lagoons, bays and islands; water characteristics and man-made modifications.

The major threats facing the mangroves of Egypt included the exploitation of it for coastal development (urbanization); firewood, camel feed and timber by human beings; pollution, this leads to a great loss of mangrove biodiversity. The studies assessing the impacts of mangrove degradation on the ecosystem and associated communities in the Red Sea are generally scarce. The camel grazing was reported in most mangroves in the region as a major problem causing mangrove degradation, excluding only a few stands growing in protected islets along the Red Sea coast.

It is difficult to generalize planting sites for successful mangrove restoration, as this will depend on understanding of the ecological interactions and processes (ecosystem approach) and local environmental conditions along the costal and the species to be planted. in addation, the Knowledge of mangroves species zonation is essential in determining suitable areas of different species.

Therefore, urgently need to evaluate the success of rehabilitation trials of mangroves that implemented before along the Red Sea coast to contribute in success of current and future conservation activities for mangroves. Thus, our focus should be extended to improving management and policy in mangrove restoration as forest carbon stock enhancement. This holistic effort would increase the benefit of mangrove ecosystem services for communities and human beings.

The Egyptian government aims to achieve Greenhouse Gas (GHG) emission reduction targets and the information of the carbon stored and emitted from Egypt mangroves is available. This information will support sound policy decision and forest management for climate change mitigation. However, the current study highlights the importance of strengthening GHG emission inventory by further involvement of mangroves carbon into carbon forest accounting at the Egyptian national level.

\section{Acknowledgment}

Acknowledgments: I really appreciate the support and advice from experts, mentors, and colleagues who guided and helped me through my career and field work as a mangrove ecologist. I express my deepest thanks and grateful appreciation to (in alphabetical order, prefixes and titles omitted): Atsushi Nakashima; Chiharu Miyamoto; Hiroshi Nawata; Ichido Yoshimori; Ken Yoshikawa; Moustafa Fouda; Taher Issa; Tomohiro Teraminami; and all the staff of "the 
Research Institute for Humanity and Nature (RIHN), Kyoto, Japan" and "ACTMANG, Tokyo, Japan".

\section{References}

Abdelwahab A. Afefe, El-Bialy E. Hatab, Mohamed S. Abbas, El-Sayed I. Gaber. (2016). Assessment of Threats to Vegetation Cover in Wadi El Rayan Protected Area, Western Desert, Egypt. International Journal of Conservation Science, Volume 7, Issue 3, 2016 : 691-708.

Abdelwahab A. Afefe, Mohamed S. Abbas Amira Sh. Soliman, Abdel-Hamid A. Khedr, ElBialy E. Hatab. (2019). Physical and chemical characteristics of mangrove soil under marine influence. A case study on the Mangrove Forests at Egyptian-African Red Sea Coast. Egyptian Journal of Aquatic Biology \& Fisheries. Vol. 23(3): 385 -399.

Abdelwahab A. Afefe, Mohamed S. Abbas, Amira Sh. Soliman, Abdel-Hamid A. Khedr, ElBialy E. Hatab. (2020). Tree biomass and soil carbon stocks of a mangrove ecosystem on the Egyptian-African Red Sea coast. Fundamental and Applied Limnology/ E. Schweizerbart'sche Verlagsbuchhandlung. FAL 193, issue 3.

Abdelwahab A. Afefe. (2020). Composition and changes in the spontaneous flora of the Wadi El Rayan Ramsar site, Fayoum, Egypt, in the last 20 years. Limnological Review, Sciendo. Volume 20: Issue 3.

Abdelwahab A. Afefe. (2021). Inventory and Conservation of Wild Flora in Gebel Shayeb ElBanat as a Potential Protected Area, the Red Sea Region, Egypt. Aswan University Journal of Environmental Studies (AUJES). Article 2, Volume 2, Issue 1, Winter 2021, Page 11-25

Anonymous (2006). Assessment and Management of Mangrove Forestes in Egypt for Sustainable Utilization Development. ITTO, Japan in association with MALR, MSEA, EEAA, Cairo, Egypt. Progress Report No. 6, 176pp.

Anthony B. (2007). The dual nature of parks: attitudes of neighbouring communities towards Kruger National Park, South Africa. Environmental Conservation, 34:236-245.

Armstrong D, Seddon P. (2008). Directions in re-introduction biology. Trends in Ecology and Evolution, 23: 20-25.

Aswani S, Weiant P. (2004). Scientific evaluation in women's participatory management: monitoring marine invertebrate refugia in the Solomon Islands. Human Organization 63(3):301-319.

Batanouny K. (1986). Ecology and plant life in the state of Qatar, 1st edition, Qatar University, Ad-Doha, 414pp. (in Arabic). 
Beer M., Voelpel S, Leibold M, Tekie E. (2005). Strategic management as organizational learning: developing fit and alignment through a disciplined process, Long Range Planning, 38(5), pp. 445-465.

Bosire J. (1999). Floristic and faunistic secondary succession in a mangrove ecosystem in Kenya. MSc Thesis, Vrije Universiteit Brussels, Belgium, 158pp

Cornforth A, Fatoyinbo E, Freemantle P, Pettorelli N. (2013). Advanced Land Observing Satellite Phased Array Type L-Band SAR (ALOS PALSAR) to Inform the Conservation of Mangroves: Sundarbans as a Case Study. Remote Sens, 5, 224 - 237.

Crooks S, Herr D, Laffoley D, Tamelander J, Vandever J. (2011). Regulating Climate Change through Restoration and Management of Coastal Wetlands and Near-shore Marine Ecosystems: Mitigation Potential and Policy Opportunities. World Bank, IUCN, ESA PWA, Washington, Gland, San Francisco. Pp. 60

Dahdouh-Guebas F. (2001). Mangrove vegetation structure dynamics and regeneration. $\mathrm{PhD}$ Thesis, APNA, Vrije Universiteit Brussels, Belgium, 144pp

Dahdouh-Guebas F, Mathenge C, Kairo J, Koedam N. (2000). Utilization of mangrove wood products around Mida Creek (Kenya) among subsistence and commercial users. Economic Botany, 54: 513-527

Dittmar T, Hertkorn N, Kattner G, Lara R. (2006). Mangroves, a major source of dissolved organic carbon to the oceans. Global Biogeochem Cycles, 20(1): 1-7

Dodd R, Ong J. (2008). Future of mangrove ecosystems to 2025. In: Polunin, N.V.C. (Ed.), Aquatic Ecosystems: Trends and Global Prospects. Foundation for Environmental Conservation, Cambridge University Press, Cambridge, pp. 172-187.

Donato D, Kauffman J, Mackenzie R, Ainsworth A, Pfleeger A. (2012). Whole-island carbon stocks in the tropical Pacific: implications for mangrove conservation and upland restoration. Journal of Environmental Management, 97:89-96.

Egyptian Environmental Affairs Agency (EEAA). (1998). Red Sea Coastal Marine Protected Area Strategy, Egyptian Red Sea Coastal and Marine Resource Management Project, EEAA, Egypt, 84 pp.

Egyptian Environmental Affairs Agency (EEAA). (2009). Assessment and Management of Mangrove Forest in Egypt for Sustainable Utilization and Development. Final report project, funded by The International Tropical Timber Organization, 65pp

Ellison A. (2008). Managing mangroves with benthic biodiversity in mind: moving beyond roving banditry. Journal of Sea Research, 59(1-2), 2-15.

Ellison A. (2000). Mangrove restoration: Do we know enough?. Restoration Ecology, 8: 219229 
FAO (1985). Mangrove management in Thailand, Malaysia and Indonesia. FAO Environment Paper, Rome, pp 60

FAO (1994). Mangrove forest management guidelines. FAO Forestry Paper 117. Rome, pp 320

FAO (2001). Socio-Economic and Gender Analysis (SEAGA) Programme. Field Level Handbook. Gender and Development Service, FAO, Rome.140 pp

Field C. (1996). Restoration of mangrove Ecosystems. International Tropical Timber Organization and International Society for Mangrove Ecosystems, Okinawa, Japan. pp.250

Field C. (1998). Rationales and practices of mangrove afforestation. Marine and Freshwater Research, 49: 353-358

Flint R, Herr D, Vorhies F, Smith J. (2018). Increasing success and effectiveness of mangrove conservation investments: A guide for project developers, donors and investors. IUCN, Geneva, Switzerland, and WWF Germany, Berlin, Germany, pp. 106

Fouda M, Gerges A. (1994). Implication of climate change in the Red Sea and Gulf of Aden Region: An Overview. UNEP Regional Seas Reports and Studies No. 156. in cooperation with PERSGA. 99 pp.

Giri C, Ochieng E, Tieszen L, Zhu Z, Singh A, Loveland T, Masek J, Duke N. (2011). Status and distribution of mangrove forests of the world using earth observation satellite data (version 1.3, updated by UNEP-WCMC). Global Ecology and Biogeography, 20: 154-159.

Hassib M. (1951). Distribution of plant communities in Egypt. Bull. Fac. Sci. Univ. Fouad I, Cairo, Egypt, 29: 59-261.

Hockings M, Stolton S, Leverington F, Dudley N, Courrau J. (2006). Evaluating Effectiveness: A framework for assessing management effectiveness of protected areas. 2nd edition. IUCN, Gland, Switzerland and Cambridge, UK. 105 pp.

Hoffman W, Durako M, Lewis R. (1985). Habitat restoration in Tampa bay. In: Simon SAF, Lewis JL III, Whiman RR, RL Jr (eds) Treat, Proc. Tampa Bay Area Scientific Inf. Symp. Florida Sea Grant College, Bellwether Press, pp 636-657

Horwitz P, Finlayson M, Weinstein P. (2012). Healthy wetlands, healthy people: a review of wetlands and human health interactions. Ramsar Technical Report No. 6. Secretariat of the Ramsar Convention on Wetlands, Gland, Switzerland \& the World Health Organization, Geneva, Switzerland. 114pp

Kairo J. (1995a). Artificial regeneration and sustainable yield management of mangrove forests in Gazi Bay, Kenya. MSc Thesis, University of Nairobi, Nairobi, Kenya, pp 116

Kairo J. (1995b). Community participatory forestry for rehabilitation of deforested mangrove areas of Gazi Bay (Kenya). A first approach. Final technical report. University of Nairobi, Department of Botany, Nairobi, Kenya. 108pp 
Kairo J. (2001). Ecology and restoration of mangrove systems in Kenya. PhD thesis, APNA, Vrije Universiteit Brussels, Belgium. pp.127

Kauffman J, Donato D. (2012). Protocols for the Measurement, Monitoring and Reporting of Structure, Biomass and Carbon Stocks in Mangrove Forests. Working Paper 86; CIFOR: Bogor, Indonesia. pp.50

Khalil A. (2001). Response of meiofauna to mangrove deforestation in arid coastal habitats of the Red Sea (Sudan) with emphasis on free-living marine nematodes. PhD Thesis, Zentrum für Marine Tropenökologie, Bremen, 82 pp

Lewis R. (1990). Creation and restoration of coastal wetlands in Puerto Rico and the US Virgin Islands. In: Kusler JA, Kentula ME (eds) Wetland Creation and Restoration: The Status of Science, Vol. I: Regional Reviews, Island Press, Washington DC, pp 103-123 A6

Liu H, Ren H, Hui D, Wang W, Liao B, Cao Q. (2014). Carbon stocks and potential carbon storage in the mangrove forests of China. J. Environ. Manag., 133: 86-93.

Luther D, Greenberg R. (2009). Mangroves: a global perspective on the evolution and conservation of their terrestrial vertebrates. BioScience, 59(7): 602-612.

Macintosh D, Ashton E. (2002). A Review of Mangrove Biodiversity Conservation and Management. Centre for Tropical Ecosystems Research, Denmark, University of Aarhus. pp. 86

McKee K, Faulkner P. (2000). Restoration of biogeochemical function in mangrove forests. Restoration Ecology 8: 274-259

Meaden G, Aguilar-Manjarrez J. (2013). Advances in geographic information systems and remote sensing for fisheries and aquaculture. FAO Fisheries and Aquaculture Technical Paper, No. 552. Rome, FAO. 425 pp.

Milica D. (2011). Guide to the logical framework approach. European integration office. GSM Advertising, Belgrade. pp. 41

Mohamed S. Abbas, Abdelwahab A. Affef, El-Bialy E. Hatab, El-Sayed I. Gaber (2016). Vegetation-Soil Relationships in Wadi El-Rayan Protected Area, Western Desert, Egypt. Jordan Journal of Biological Sciences. Volume 9, Number 2, June .2016- ISSN 19956673.

Najeeb M, Ian C. (2015). The Red Sea: The Formation, Morphology, Oceanography and Environment of a Young Ocean Basin. Springer-Verlag GmbH Berlin Heidelberg is part of Springer Science Business Media, 638 pp.

Naoko Matsu, Ryo Banjo, Tomohiro Teraminami, Abdelwahab Affef , Amgad EL-Shaffal, Atsushi Nakashima, Hiroshi Nawata, and Ken Yoshikawa (2016). Branch Morphology of a Mangrove (Avicennia marina (Forsk.) Vierh) Growing in a Per-Arid 
Area on the Egyptian Red Sea Coast Regulates Water Use of Its Leaves. Journal of Arid Land Studies. 26-3, 91-94 (2016)

Nellemann C, Corcoran E, Duarte C, Valdés L, De Young C, Fonseca L, Grimsditch G. (2009). Blue Carbon. A Rapid Response Assessment. United Nations Environment Programme, GRID-Arendal. This report is produced as an inter-agency collaboration between UNEP, FAO and IOC/UNESCO. pp. 1:80

Paramaraj M. (2004). Eco-Physiological Studies of Mangroves in Tuticorin District, Tamilnadu. PhD Thesis, Manonmaniam Sundaranar University, India. pp. 189

Pendleton L, Donato D, Murray B, Crooks S, Jenkins W, Sifleet S, Craft C, Fourqurean J, Kauffman J, Marbà N, Megonigal P, Pidgeon E, Herr D, Gordon D, Baldera A. (2012). Estimating global blue carbon emissions from conversion and degradation of vegetated coastal ecosystems, PLoS One,7: 1-7

PERSGA. (2004). Status of Mangroves in the Red Sea and Gulf of Aden. Technical Series Number 11, PERSGA, Jeddah, 67 pp.

PERSGA. (2011). Regional guidelines for mangrove restoration in the Red Sea and Gulf of Aden. PERSGA Guidelines No. GD-0010, PERSGA, Jeddah, pp 1-34.

Pulver T. (1976). Transplant techniques for sapling mangrove trees, Rhizophora mangle, Laguncularia racemosa and Avicennia germinans, in Florida. Florida Marine Research Publications 22. Contribution No. 282, St. Petersburg, Florida, USA, pp 14

Rabinowitz D. (1978). Early growth of mangrove seedlings in Panama, and an hypothesis concerning the relationship of dispersal and zonation. Journal of Biogeography, 5: 113-133

Ramsar. (2010). Managing wetlands: Frameworks for managing Wetlands of International Importance and other wetland sites. Ramsar handbooks for the wise use of wetlands, 4th edition, vol. 18. Ramsar Convention Secretariat, Gland, Switzerland. pp. 98

Reed M. (2008). Stakeholder participation for environmental management: a literature review. Biological Conservation, 141:2417-2431.

Roberts R, Ruara W. (1967). Lamu mangroves inventory. Part 1 and 2. Spartan Air Services (Canada) and Forest Department, Nairobi. Ministry of Environment and Natural Resource, Kenya. 155 pp.

Saenger P, Khalil A. (2007). Regional action plan for the conservation of mangroves. In: PERGA/GEF Regional action plan for the conservation of marine turtles, seabirds and mangroves in the Red Sea and Gulf of Aden. Technical Series 12, PERSGA, Jeddah, pp $101-129$

Saenger P, Siddique N. (1993). Land from the sea: the afforestation program of Bangladesh. Ocean and Coastal Management, 20: 23-39 
Scholander P, Hammel H, Hemmimgsen E, Garey W. (1962). Salt balance in mangrove. Plant Physiol., 37:722- 729.

Semesi A. (1998). Mangrove management and utilization in eastern Africa. Ambio 27: 620-626

Semesi, A.K. and Howell, K. (1992): The mangroves of the East African region. UNEP, Nairobi. 34 pp.

Siddique N, Islam M, Khan M, Shahidulla M. (1993). Mangrove nurseries in Bangladesh. Mangrove Ecosystem Occasional, Papers 1. ISME. Okinawa, pp 14

Simon N, Cras A, Foulon E, Lemee R. (2009). Diversity and evolution of marine phytoplankton. Comptes Rendus Biologies, 332: 159-170.

Slobodian L, Rodriguez Chaves M, Nguyen L, Rakotoson L. (2018). Legal frameworks for mangrove governance, conservation and use: Assessment summary. IUCN, Geneva, Switzerland, and WWF Germany, Berlin, Germany, (74) pp.

Spalding M, Kainuma K, Collins L. (2010). World Atlas of Mangroves. A collaborative project of ITTO, ISME, FAO, UNEP-WCMC, UNESCO-MAB, UNU-INWEH and TNC. Earthscan, London. 48 pp.

TNC. (2000). The Five-S Framework for Site Conservation: A Practitioner's Handbook for Site Conservation Planning and Measuring Conservation Success, Volume I, Second Edition. The Nature Conservancy, Arlington, Virginia. 58 pp.

Tomohiro Teraminami, Atsushi Nakashima, Mao Ominami, Naoko Matsuo, Ryo Nakamura, Hiroshi Nawata, Abdelwahab A. Abdelwahab, Amgad A. ElShaffai, Ken Yoshikawa. (2013). Effects of shoot position on shoot and leaf morphology of Avicennia marina in the hyperarid Red Sea coastal region of Egypt. Landscape and Ecological Engineering. 2013, 1-9.

Tundi A, John D, Kristin S, Ole V. (2011). Taking Steps toward Marine and Coastal Ecosystem-Based Management- An Introductory Guide,UNEP Division for E;;.nvironmental Policy Implementation, Freshwater and Marine Ecosystems Branch, (68) pp.

Zahran M, Willis A. (2009). The vegetation of Egypt. Springer, 2nd edition, 437 pp. 


\section{Annex}

\section{Further Actions to Support Site-based Conservation of Mangroves:}

The present study provides the following table to gives a general guidance to address a broad range and scale of management challenges and solutions for mangrove conservation. These are not exhaustive but indicative of the types of actions that are needed and to the likely concerned agencies for implementation.

\begin{tabular}{|c|c|c|}
\hline $\begin{array}{l}\text { Demarcation - } \\
\text { Boundaries }\end{array}$ & Targeted Actions & $\begin{array}{c}\text { Lead } \\
\text { Agencies }\end{array}$ \\
\hline Demarcation & $\begin{array}{l}\text { - Dimensions of these areas need to be clearly marked } \\
\text { and the appropriate fencing should be built around each } \\
\text { stand. }\end{array}$ & EEAA \\
\hline Boundaries & $\begin{array}{l}\text { - The stand itself should be considered as a core area } \\
\text { with a corresponding buffer area of appropriate size } \\
\text { including the mud flat area. } \\
\text { - An additional extension zone should be established for } \\
\text { each stand to allow for growth and rehabilitation } \\
\text { experiments. }\end{array}$ & EEAA \\
\hline Signs & $\begin{array}{l}\text { - An interpretive exhibit/sign should be included with a } \\
\text { site map in an appropriate place. }\end{array}$ & EEAA \\
\hline $\begin{array}{l}\text { Monitoring } \\
\text { and } \\
\text { Rehabilitation }\end{array}$ & Targeted Actions & \\
\hline Plan & $\begin{array}{l}\text { - A monitoring programme and site-based plan needs to } \\
\text { be developed. }\end{array}$ & EEAA \\
\hline Rehabilitation & $\begin{array}{l}\text { - This should include: a) the measurement of boundary } \\
\text { and zoning effectiveness and b) rehabilitation needs, } \\
\text { and c) pollution, health and disease considerations. }\end{array}$ & $\begin{array}{l}\text { EEAA, } \\
\text { MAL }\end{array}$ \\
\hline Methods & $\begin{array}{l}\text { - Monitoring should be divided on geographical bases to } \\
\text { minimize the effort, and use standard internationally } \\
\text { recognized methodology. }\end{array}$ & EEAA, URI \\
\hline Training & $\begin{array}{l}\text { - Rangers should be trained on the monitoring and } \\
\text { management of mangrove stands in addition to the } \\
\text { basic biological information about the ecosystem. }\end{array}$ & EEAA, URI \\
\hline $\begin{array}{c}\text { Fisheries } \\
\text { Management }\end{array}$ & Targeted Actions & \\
\hline Licensing & $\begin{array}{l}\text { - Each of the fishermen using the mangrove sites should } \\
\text { have a license for fishing in this area. }\end{array}$ & $\begin{array}{c}\text { EEAA, } \\
\text { GDF, MAL }\end{array}$ \\
\hline Gear & $\begin{array}{l}\text { - The fishing of small fishes for bait should be forbidden } \\
\text { in mangrove areas } \\
\text { - Small mesh nets should be forbidden in mangrove sites }\end{array}$ & EEAA, GDF \\
\hline
\end{tabular}




\begin{tabular}{|c|l|c|}
\hline Seasons & $\begin{array}{l}\text { - During the fishes breading season (varying with } \\
\text { species) no fishing should be allowed in the mangrove } \\
\text { areas }\end{array}$ & $\begin{array}{c}\text { EEAA, } \\
\text { GDF, MAL }\end{array}$ \\
\hline $\begin{array}{c}\text { Other } \\
\text { Development } \\
\text { Considerations }\end{array}$ & \multicolumn{1}{|c|}{ Targeted Actions } & \multicolumn{1}{|c|}{ Targeted Actions } \\
\hline Tourism & $\begin{array}{l}\text { - Mangroves can be a valuable asset for tourism } \\
\text { (landscape, birds) and should be left intact with } \\
\text { appropriate environmental education signage in } \\
\text { relevant areas. }\end{array}$ & $\begin{array}{c}\text { MT, EEAA, } \\
\text { RSG }\end{array}$ \\
\hline $\begin{array}{c}\text { Pollution } \\
\text { Awareness } \\
\text { and Education }\end{array}$ & $\begin{array}{l}\text { An assessment of pollution impacts on mangrove stands } \\
\text { is needed per stand. }\end{array}$ & EEAA, RSG \\
\hline Target groups & $\begin{array}{l}\text { - Target groups include rangers, public, investors, and } \\
\text { students. }\end{array}$ & RSG, EEAA \\
\hline Approaches & $\begin{array}{l}\text { - There needs to be comprehensive public awareness } \\
\text { campagins with video, TV, radio, flyer, all noting links } \\
\text { with other coastal-marine ecosystems. }\end{array}$ & RSG, EEAA \\
\hline Education & $\begin{array}{l}\text { - Field trips for students at all levels (primary, secondary, } \\
\text { university) should be encouraged }\end{array}$ & $\begin{array}{c}\text { RSG, URI, } \\
\text { EEAA }\end{array}$ \\
\hline
\end{tabular}

Table Legend:

\begin{tabular}{|ll|}
\hline EEAA & Egyptian Environmental Affairs Agency \\
GDF & General Authority for Development of Fish Resources \\
RSG & Red Sea governorate \\
URI & Universities and Research Institutions \\
MT & Ministry of Tourism \\
MAL & Ministry of Agriculture \\
\hline
\end{tabular}

